\title{
Best Management Practices for the Conversion of Established Bermudagrass to Buffalograss
}

\author{
Jared. A. Hoyle and Gerald M. Henry ${ }^{1}$ \\ Department of Crop and Soil Sciences, University of Georgia, 3111 Miller \\ Plant Sciences Building, Athens, GA 30602
}

Travis Williams, Aaron Holbrook, Tyler Cooper, Leslie L. Beck, and Andrew J. Hephner

Department of Plant and Soil Science, Texas Tech University, Campus Box 42122, Lubbock, TX 79409

Additional index words. cultivation, renovation, seedbed preparation, turfgrass, water conservation

\begin{abstract}
Growing concern over the sufficiency and variability of present water supplies in the arid Southwest has led to the examination of buffalograss [Buchloe dactyloides (Nutt.) Engelm.] for water conservation. Increasing acceptance of buffalograss will require investigation into conversion techniques for its establishment. The objectives of this study were to evaluate the effects of seedbed preparation and seeding rate on the establishment of buffalograss after bermudagrass desiccation with glyphosate. Research was conducted at the Texas Tech Quaker Research farm in 2009 and 2010 on a mature 'Riviera' common bermudagrass [Cynodon dactylon (L.) Pers.] rough. Bermudagrass was sprayed with glyphosate at $1.1 \mathrm{~kg}$ acid equivalent (ae)/ha 5 and 1 weeks before seedbed preparation. Plots were scalped after desiccation. Treatments were arranged in a two $\times$ four factorial, randomized complete block design with four replications. two buffalograss seeding rates and four seedbed preparation treatments. Seedbed preparation treatments consisted of no seedbed preparation, topdressing alone $(0.6-\mathrm{cm}$ layer), hollow-tine aerification + topdressing, or verticutting + topdressing. 'TopGun' buffalograss was planted on 1 June 2009 and 4 June 2010 at 146 or $195 \mathrm{~kg} \cdot \mathrm{ha}^{-1}$. Grid counts were conducted to determine buffalograss cover one, two, and three months after planting (MAP). Counts were then converted to percent cover $(0 \%$ to $100 \%)$. Greater buffalograss cover was observed when seed was applied at the higher rate $\left(196 \mathrm{~kg} \cdot \mathrm{ha}^{-1}\right)$ except within treatments that did not receive seedbed preparation treatment. No seedbed preparation resulted in unacceptable buffalograss cover. Percent buffalograss cover three MAP was $75 \%, 83 \%$, and $86 \%$ for topdressing alone, aerification + topdressing, and verticutting + topdressing treatments seeded at $195 \mathrm{~kg} \cdot \mathrm{ha}^{-1}$, respectively.
\end{abstract}

Water conservation efforts have recently intensified in the arid Southwest as a result of increases in urbanization and local drought conditions, which have resulted in reduced amounts of water available for irrigating turfgrass (Ervin and Koski, 1998; Kjelgren et al., 2000). The fact that urban expansion is occurring simultaneously with overuse of water supplies (i.e., the Ogallala Aquifer) has created a challenge for water conservation in this region (Rodiek, 1984; Sophocleous, 2012).

Received for publication 3 Oct. 2012. Accepted for publication 8 Jan. 2013.

We thank the U.S. Golf Association for funding this research.

Mention of trade names or commercial products in this publication is solely for the purpose of providing specific information and does not imply recommendation or endorsement by the University of Georgia.

${ }^{1}$ To whom reprint requests should be addressed; e-mail jah0040@uga.edu.
Therefore, exploration of species with increased drought tolerance is advantageous.

The present water supply concerns in western Texas and other areas of the arid Southwest have led to the examination of buffalograss as a viable option for managed turfgrass environments (Frank et al., 2002, 2004). Research efforts have identified buffalograss as a reduced irrigation and fertilization input turfgrass relative to traditional turfgrass species grown in the arid Southwest (Frank et al., 2004). Qian and Engelke (1999) reported that 'Prairie' buffalograss only required 26\% irrigation based on pan evaporation to maintain acceptable turfgrass quality over a four-year period. Henry et al. (2005) observed that buffalograss performed equally at $100 \%$ and $70 \%$ of calculated evapotranspiration when receiving $0.98 \mathrm{~kg} / 100 \mathrm{~m}^{2}$ or $1.96 \mathrm{~kg} / 100 \mathrm{~m}^{2}$ of nitrogen fertility, respectively. Wu and Lin (1994) characterized the salt tolerance of buffalograss as moderate and attributed this response to an exclusion mechanism found in root tissue. Recent breeding efforts led to the release of improved turf-type buffalograss varieties such as 'Cody' and 'Bowie' in 2005 (Severmutlu et al., 2005a, 2005b). These new varieties were denser, finer-textured, and adapted to a wider range of environments compared with older varieties when tested in the 1991 and 1996 National Turfgrass Evaluation Program buffalograss trials (Morris, 1996). Increases in appearance and adaptability of buffalograss through breeding efforts have further enhanced its acceptance as a viable turfgrass option for home lawns and golf courses (Kenworthy et al., 1999; Koski et al., 2001; Zhang et al., 2007).

Buffalograss is typically established from seed as a result of increased availability, reduced cost, and ease of application (Fry, 1995; Wu et al., 1989). Recommended seeding rates range from 147 to $294 \mathrm{~kg} \cdot \mathrm{ha}^{-1}$ (Fry, 1995; Gaitan-Gaitan et al., 1999; Harivandi and Wu, 1995; Riordan et al., 1997) depending on the cultivar and seed pre-treatment (i.e., deburring) (Shearman et al., 2005). Buffalograss seed burrs are difficult to degrade and contain oil that may inhibit germination and seedling development (Ahring and Todd, 1977; Gaitan-Gaitan et al., 1999; Harivandi and Wu, 1995; Hickey et al., 1983; Riordan et al., 1997; Shearman et al., 2005; Wenger, 1943). Although sufficient work on seeding rates has been conducted, minimal research has been conducted on the influence of cultural practices on establishment.

Bermudagrass [Cynodon dactylon (L.) Pers.] is the primary warm-season turfgrass species grown in the United States (Christians, 2011). The abundant production of aggressive rhizomes and stolons enables bermudagrass to tolerate wear and recover from stress (Beard, 1973; Youngner, 1961); however, this may also make it difficult to control during conversion to buffalograss.

Traditional renovation practices usually involve the desiccation of existing turfgrass through the application of a non-selective herbicide followed by seedbed preparation (Turgeon, 2011). Jordan (1977) reported 91\% bermudagrass control $21 \mathrm{~d}$ after treatment in response to glyphosate applied at $1.1 \mathrm{~kg}$ ae/ha in the greenhouse. However, Johnson (1988) noted that three applications (May, June, and August) of glyphosate at $2.2 \mathrm{~kg}$ ae/ha were necessary to reduce bermudagrass cover of 'Tifway', 'Tifgreen', 'Tifdwarf', and 'Ormond' to less than $2 \%$ one year after treatment. Griffin et al. (1994) observed similar results (greater than $95 \%$ control) of common bermudagrass in response to sequential applications of glyphosate $(2.2 \mathrm{~kg}$ ae/ha) in June, July, and September. Multiple applications of glyphosate are commonly recommended as an effective method for the conversion of turfgrass sites (Hartwiger, 2007; Roundup Pro ${ }^{\circledR}$ Specimen Label, 2010).

The objectives of this study were to evaluate the effects of seedbed preparation methods and seeding rate on the establishment of buffalograss after bermudagrass desiccation with glyphosate. Results may provide turfgrass managers insight into effective conversion practices for the establishment of buffalograss. 


\section{Materials and Methods}

Field trials were conducted at the Texas Tech Quaker Research Farm in Lubbock,

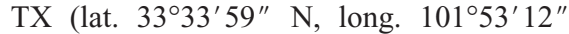
W) during the summer of 2009 and 2010 . Before the initiation of research, a mature stand of 'Riviera' common bermudagrass established from seed in 2004 was sprayed with glyphosate (Roundup Pro ${ }^{\circledR}$; Monsanto Company, St. Louis, MO) at $1.1 \mathrm{~kg}$ ae/ha 5 weeks before trial initiation and again 1 week prior. Soil was a Brownfield Sandy Clay Loam (loamy, mixed, superactive, thermic Arenic Aridic Paleustalfs) with a $\mathrm{pH}$ of 8.0 and organic matter content of $1.3 \%$. The research area was scalped to a height of $0.6 \mathrm{~cm}$ with a rotary mower (American Honda Motor Co., Inc., Torrance, CA) after desiccation and clippings were removed.

Experimental design was a two $\times$ four factorial, randomized complete block design with four replications. Factors were the combination of two buffalograss seeding rates (146 and $195 \mathrm{~kg} \cdot \mathrm{ha}^{-1}$ ) and four seedbed preparation techniques (no preparation, topdressing alone, aerification + topdressing, and verticutting + topdressing). Individual treatments were applied to $1.2 \times 1.8-\mathrm{m}$ plots. On 1 June 2009 and 4 June 2010, treatments were applied. Hollow-tine aerification to a depth of $5.1 \mathrm{~cm}$ was performed with a Toro Pro Core 648 Aerator (The Toro Company, Bloomington, MN) equipped with $1.3-\mathrm{cm}$ diameter tines on 6.4-cm $\times 6.4-\mathrm{cm}$ spacing. Verticutting to a depth of $1.9 \mathrm{~cm}$ was conducted in two directions perpendicular to each other with a Graden GS04 verticutter (Graden Industries Pty. Ltd., Victoria, Australia) with blades spaced $2.5 \mathrm{~cm}$ apart. Sand topdressing $[8.7 \%$ very coarse sand $(1.0$ to $2.0 \mathrm{~mm}), 24.8 \%$ coarse sand $(0.5$ to $1.0 \mathrm{~mm})$, $40.2 \%$ medium sand ( 0.25 to $0.5 \mathrm{~mm}), 21.0 \%$ fine sand $(0.15$ to $0.25 \mathrm{~mm})$, and $5.3 \%$ very fine sand $(0.05$ to $0.15 \mathrm{~mm})]$ (R E Janes Gravel Co., Slaton, TX) was applied to a depth of $0.6 \mathrm{~cm}$. Aerification and verticutting were conducted before the seeding of each plot with deburred 'TopGun' buffalograss (Bamert Seed Company, Muleshoe, TX) applied using a shaker jar. Deburred seed was used because buffalograss seed burrs are difficult to degrade and contain oil, which may inhibit seed germination (Harivandi and $\mathrm{Wu}, 1995)$. All plots were lightly brushed after topdressing with a soft bristle broom to ensure good seed-to-soil contact. Treatment regimens are presented in Table 1 to show corresponding treatment numbers. Fertilizer (7N-3.1P-5.8K) (Green Spec Fertilizer; Griggs Brothers, Albion, ID) was applied at the time of seeding at a rate of $49 \mathrm{~kg}$ nitrogen/ha. Irrigation was applied daily with an automated irrigation system calibrated to deliver $5 \mathrm{~cm} /$ week to ensure adequate soil moisture and mown weekly at a height of $5 \mathrm{~cm}$ throughout the duration of the trial.

Grid counts were conducted to assess buffalograss cover one, two, and three MAP. A $0.3-\mathrm{m}^{2}$ grid with $2.5-\mathrm{cm} \times 2.5-\mathrm{cm}$ intersect spacing was randomly placed within each plot. The following equation was used to convert grid counts to percent cover:

$$
(a / b) \times 100=c
$$

where $a$ is the number of intersects where buffalograss was present, $b$ is the total number of intersections (25), and $c$ is percent buffalograss (Richardson et al., 2001).

Analysis of variance was performed in SAS (SAS Version 9.2; SAS Institute Inc., Cary, NC) using the appropriate expected mean square values described by McIntosh (1983). Buffalograss data were arcsine squareroot transformed before analysis (Bowley, 2008). Interpretations were not different from non-transformed data; therefore, nontransformed means are presented for clarity (Table 2). Contrast statements were conducted according to initial objectives using PROC GLM for each seeding rate and pooled across seeding rates. Contrasts included low seeding rate vs. high seeding rate (contrast only conducted across seeding rates); topdressing vs. non-topdressing; invasive cultural practices vs. non-invasive cultural practices; invasive cultural practices vs. topdressing alone; and verticutting vs. aerification. All contrasts are presented in Table 3 with corresponding treatment numbers (Table 1).

\section{Results and Discussion}

A significant experimental run-by-treatment interaction $(F=1, P=0.454)$ was not observed; therefore, data were pooled across experimental runs. Significant seeding rate $(F=200.2, P<0.001)$ and seedbed preparation $(F=425.9, P<0.001)$ main effects as well as an interaction between seeding rate and seedbed preparation $(F=20.7, P<0.001)$ were observed for buffalograss cover. Buffalograss cover increased in response to the higher seeding rate at all rating dates for all seedbed preparation techniques except the no seedbed preparation treatment (Table 2). This was supported through the conduction of planned pairwise comparisons (Table 3 ). Contrasts comparing pooled low seeding rate treatments with pooled high seeding rate treatments were significant $(P<0.001)$ at one, two, and three MAP. Buffalograss cover increased $12 \%, 17 \%$, and $19 \%$ at one, two, and three MAP, respectively, when comparing pooled low seeding rate treatments with pooled high seeding rate treatments. Harivandi et al. (1995) observed similar results when seeding deburred 'Hilite 25' buffalograss although seeding rates were less than those

Table 1. Treatment regimes ${ }^{\mathrm{z}}$ for bermudagrass (Cynodon dactylon) conversion to buffalograss (Buchloe dactyloides) research trials.

\begin{tabular}{|c|c|c|}
\hline Treatment number & Buffalograss seeding rate ${ }^{y}$ & Seedbed preparation \\
\hline 1 & $146 \mathrm{~kg} \cdot \mathrm{ha}^{-1}$ & No preparation \\
\hline 2 & $146 \mathrm{~kg} \cdot \mathrm{ha}^{-1}$ & Topdressing ${ }^{\mathrm{x}}$ alone \\
\hline 3 & $146 \mathrm{~kg} \cdot \mathrm{ha}^{-1}$ & Verticutting $^{\mathrm{w}}+$ topdressing \\
\hline 4 & $146 \mathrm{~kg} \cdot \mathrm{ha}^{-1}$ & Aeration $^{\mathrm{v}}+$ topdressing \\
\hline 5 & $195 \mathrm{~kg} \cdot \mathrm{ha}^{-1}$ & No preparation \\
\hline 6 & $195 \mathrm{~kg} \cdot \mathrm{ha}^{-1}$ & Topdressing alone \\
\hline 7 & $195 \mathrm{~kg} \cdot \mathrm{ha}^{-1}$ & Verticutting + topdressing \\
\hline 8 & $195 \mathrm{~kg} \cdot \mathrm{ha}^{-1}$ & Aeration + topdressing \\
\hline
\end{tabular}

Table 2. Influence of seeding rate and seedbed preparation on buffalograss (Buchloe dactyloides) establishment one, two, and three months after planting (MAP).

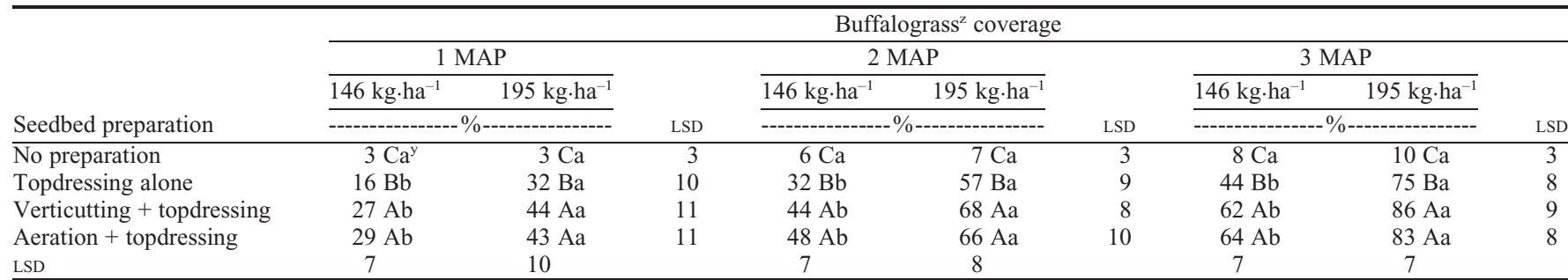

z‘TopGun' buffalograss planted 1 June 2009 and 4 June 2010.

${ }^{y}$ Means within a column followed by the same uppercase letter are not significantly different at $P \leq 0.05$ according to Fisher's Protected LsD test. Means within a row followed by the same lowercase letter are not significantly different at $P \leq 0.05$ according to Fisher's protected LSD test. LSD $=$ least significant difference. 
Table 3. Pooled treatment means and pairwise contrasts ${ }^{\mathrm{z}}$ conducted on buffalograss (Buchloe dactyloides) establishment methods one, two, and three months after planting (MAP).

\begin{tabular}{|c|c|c|c|c|}
\hline \multirow[b]{3}{*}{ Seeding rate } & \multirow[b]{2}{*}{ Treatments } & \multicolumn{3}{|c|}{ Buffalograss coverage } \\
\hline & & 1 MAP & 2 MAP & 3 MAP \\
\hline & Contrasts & \multicolumn{3}{|c|}{ 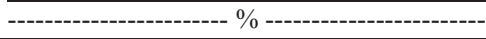 } \\
\hline \multirow[t]{5}{*}{$\begin{array}{l}146 \mathrm{~kg} \cdot \mathrm{ha}^{-1} \text { and } \\
195 \mathrm{~kg} \cdot \mathrm{ha}^{-1 \mathrm{y}}\end{array}$} & $\begin{array}{l}\text { Low seeding rate }{ }^{\mathrm{x}}(1,2,3,4) \text { vs. high } \\
\quad \text { seeding rate }(5,6,7,8)\end{array}$ & 19 vs. $31^{* * *}$ & 33 vs. $50^{* * *}$ & 45 vs. $64 * * *$ \\
\hline & $\begin{array}{l}\text { Topdressing }(2,3,4,6,7,8) \text { vs. } \\
\text { non-topdressing }(1,5)\end{array}$ & 32 vs. $3 * * *$ & 53 vs. $7 * * *$ & 70 vs. $9 * * *$ \\
\hline & $\begin{array}{l}\text { Invasive cultural practices } \\
(3,4,7,8) \text { vs. non- invasive } \\
\text { cultural practices }(1,2,5,6)\end{array}$ & 36 vs. $14^{* * *}$ & 57 vs. $26^{* * *}$ & 74 vs. $34 * * *$ \\
\hline & $\begin{array}{l}\text { Invasive cultural practices }(3,4,7,8) \text { vs. } \\
\text { topdressing alone }(2,6)\end{array}$ & 36 vs. $24 * * *$ & 57 vs. $45^{* * * *}$ & 74 vs. $60 * * *$ \\
\hline & Verticutting $(3,7)$ vs. aerification $(4,8)$ & 36 vs. $36 \mathrm{Ns}$ & 56 vs. $57 \mathrm{NS}$ & 74 vs. 74 NS \\
\hline \multirow[t]{4}{*}{$146 \mathrm{~kg} \cdot \mathrm{ha}^{-1}$} & $\begin{array}{l}\text { Topdressing }(2,3,4) \text { vs. } \\
\text { non-topdressing }(1)\end{array}$ & 24 vs. $3 * * *$ & 41 vs. $6^{* * *}$ & 57 vs. $8 * * *$ \\
\hline & $\begin{array}{l}\text { Invasive cultural practices }(3,4) \text { vs. } \\
\text { non-invasive cultural practices }(1,2)\end{array}$ & 28 vs. $10 * * *$ & 46 vs. $19 * * *$ & 63 vs. $26^{* * *}$ \\
\hline & $\begin{array}{l}\text { Invasive cultural practices }(3,4) \text { vs. } \\
\text { topdressing alone }(2)\end{array}$ & 16 vs. $10 * * *$ & 46 vs. $32 * * *$ & 63 vs. $44 * * *$ \\
\hline & Verticutting (3) vs. aerification (4) & 27 vs. $29 \mathrm{Ns}$ & 44 vs. 48 NS & 62 vs. 64 Ns \\
\hline \multirow[t]{4}{*}{$195 \mathrm{~kg} \cdot \mathrm{ha}^{-1}$} & $\begin{array}{l}\text { Topdressing }(6,7,8) \text { vs. } \\
\text { non-topdressing }(5)\end{array}$ & 40 vs. $3 * * *$ & 64 vs. $7 * * *$ & 75 vs. $10 * * *$ \\
\hline & $\begin{array}{l}\text { Invasive cultural practices }(7,8) \text { vs. } \\
\text { non-invasive cultural practices }(5,6)\end{array}$ & 44 vs. $18 * * *$ & 67 vs. $32 * * *$ & 85 vs. $43 * * *$ \\
\hline & $\begin{array}{l}\text { Invasive cultural practices }(7,8) \text { vs. } \\
\text { topdressing alone }(6)\end{array}$ & 44 vs. $32 * *$ & 67 vs. $57 * *$ & 85 vs. $75^{* *}$ \\
\hline & Verticutting (7) vs. aerification (8) & 44 vs. 43 NS & 68 vs. 66 NS & 86 vs. 83 NS \\
\hline
\end{tabular}

zooled treatment means followed by NS, * $* *, * * *$ indicate nonsignificance or significance at $P \leq 0.05$ $P \leq 0.01, P \leq 0.001$, respectively.

${ }^{y}$ Contrasts were conducted pooling over seeding rates.

${ }^{x}$ Number following contrasts refer to treatment number in Table 1.

used in our research. At the conclusion of the study by Harivandi et al. (1995), the average growth rate measurements (1 to 9,9 being best) for buffalograss seeded at 25, 49, 73, and $98 \mathrm{~kg} \cdot \mathrm{ha}^{-1}$ were $3.0,2.7,7.7$, and 6.5 , respectively (Harivandi et al., 1995). This suggests that seeding deburred buffalograss at higher rates (73 and $98 \mathrm{~kg} \cdot \mathrm{ha}^{-1}$ ) may increase turfgrass cover and reduce weed encroachment. Shearman et al. (2005) also reported an increase in buffalograss cover with increased seeding rates. Seeding 'Bowie' buffalograss at 25 to $392 \mathrm{~kg} \cdot \mathrm{ha}^{-1}$ resulted in $10 \%$ to $77 \%$ cover one MAP. The no seedbed preparation treatment in our research resulted in $10 \%$ or less buffalograss cover at all rating dates, regardless of seeding rate (Table 2). Other researchers observed 17\% cover of plugged 'Colorado Common' buffalograss four MAP in response to minimal seedbed preparation treatments (Harivandi et al., 1995).

Seedbed preparation techniques conducted at 146 and $195 \mathrm{~kg} \cdot \mathrm{ha}^{-1}$ seeding rates resulted in different buffalograss cover one, two, and three MAP (Table 2). The buffalograss seeding rate of $195 \mathrm{~kg} \cdot \mathrm{ha}^{-1}$ increased buffalograss cover, one MAP, with respect to all seedbed preparation treatments except the no seedbed preparation treatment. Verticutting + topdressing and aerification + topdressing treatments seeded at $195 \mathrm{~kg} \cdot \mathrm{ha}^{-1}$ resulted in the greatest buffalograss cover ( $44 \%$ and $43 \%$, respectively) one MAP but were not statistically different from one another as confirmed by mean separation (Table 2) and preplanned pairwise comparisons (Table 3). Similarly, Shearman et al.
(2005) observed $\approx 55 \%$ 'Bowie' buffalograss cover one MAP when buffalograss was handseeded $\left(196 \mathrm{~kg} \cdot \mathrm{ha}^{-1}\right)$, raked to incorporate seed, and rolled to firm the soil surface. Verticutting + topdressing and aerification + topdressing treatments seeded at $146 \mathrm{~kg} \cdot \mathrm{ha}^{-1}$ resulted in $17 \%$ and $14 \%$ less buffalograss cover than the high seeding rate, respectively, one MAP and where not statistically different from one another as confirmed by mean separation (Table 2) and preplanned pairwise comparisons (Table 3). Verticutting + topdressing and aerification + topdressing treatments seeded at either seeding rate resulted in higher buffalograss cover than topdressing alone. Contrasts (pooled across seeding rates) comparing invasive cultural practices (verticutting + topdressing and aerification + topdressing treatments) with topdressing alone one MAP revealed that invasive cultural practices resulted in $12 \%$ higher buffalograss cover $(P<0.001)$ (Table 3$)$. Contrasts for invasive cultural practices vs. topdressing alone also confirmed this observation one MAP when seeded at 146 and $195 \mathrm{~kg} \cdot \mathrm{ha}^{-1}$ $(P<0.001$ and $P<0.001$, respectively).

Although buffalograss cover continued to increase over time, similar results were observed between treatments two MAP (Table 2). Verticutting + topdressing and aerification + topdressing treatments seeded at both rates resulted in higher buffalograss cover than topdressing alone. Verticutting + topdressing and aerification + topdressing treatments at $146 \mathrm{~kg} \cdot \mathrm{ha}^{-1}$ resulted in $44 \%$ and $48 \%$ buffalograss cover, respectively. Buffalograss cover increased $25 \%$ and $18 \%$ in response to verticutting + topdressing and aerification + topdressing treatments, respectively, when seeded at $195 \mathrm{~kg} \cdot \mathrm{ha}^{-1}$. Verticutting + topdressing and aerification + topdressing treatments seeded at $195 \mathrm{~kg} \cdot \mathrm{ha}^{-1}$ resulted in the greatest coverage two MAP, $68 \%$ and $66 \%$, respectively. However, Shearman et al. (2005) reported $90 \%$ cover two MAP of 'Bowie' buffalograss when seeded at $196 \mathrm{~kg} \cdot \mathrm{ha}^{-1}$ and raked/rolled to ensure proper seed to soil contact. Bowie is a denser, new turf-type buffalograss that exhibits enhanced growth and a wide range of environmental adaptation that may have contributed to a greater rate of establishment (Severmutlu et al., 2005b). Topdressing alone resulted in $57 \%$ buffalograss cover when seeded at $195 \mathrm{~kg} \cdot \mathrm{ha}^{-1}$ two MAP but was significantly reduced to $32 \%$ when seeded at $146 \mathrm{~kg} \cdot \mathrm{ha}^{-1}$. The pairwise contrast comparing topdressing vs. non-topdressing resulted in a $53 \%$ vs. $7 \%$ buffalograss cover $(P<0.001)$ when pooled across seeding rates two MAP (Table 3 ). When analyzed individually at two MAP, seeding rates of $146 \mathrm{~kg} \cdot \mathrm{ha}^{-1}$ and $195 \mathrm{~kg} \cdot \mathrm{ha}^{-1}$ also resulted in a significant increase $(P<$ $0.001)$ in buffalograss cover when comparing topdressing vs. non-topdressing, $41 \%$ vs. $6 \%$ and $64 \%$ vs. $7 \%$, respectively. Similar to one MAP, buffalograss in response to no seedbed preparation resulted in less than $7 \%$ cover, regardless of seeding rate, two MAP (Table 2).

Buffalograss cover continued to increase three MAP for all seeding rates and seedbed preparation treatments (Table 2). No seedbed preparation resulted in less than $10 \%$ buffalograss cover regardless of seeding rate. Dissimilarly, Frank et al. (2002) observed 55\% 'Cody' buffalograss covers three MAP with minimal seedbed preparation (lightly raked $2.5 \mathrm{~cm}$ deep into the soil surface) when seeded a rate of $98 \mathrm{~kg}$ burrs/ha and Frank et al. (1998) observed 23\% buffalograss cover at two different locations three MAP when seeded at $100 \mathrm{~kg}$ burrs $/$ ha. Buffalograss cover $\left(44 \%\right.$ and $75 \%$ at $146 \mathrm{~kg} \cdot \mathrm{ha}^{-1}$ and $195 \mathrm{~kg} \cdot \mathrm{ha}^{-1}$, respectively) was significantly higher for topdressing as a seedbed preparation compared with no seedbed preparation $\left(8 \%\right.$ and $10 \%$ at $146 \mathrm{~kg} \cdot \mathrm{ha}^{-1}$ and $195 \mathrm{~kg} \cdot \mathrm{ha}^{-1}$, respectively) (Table 2). Verticutting + topdressing and aerification + topdressing treatments seeded at $195 \mathrm{~kg} \cdot \mathrm{ha}^{-1}$ resulted in the greatest buffalograss cover ( $86 \%$ and $83 \%$, respectively) at three MAP. Seedbed preparation of topdressing alone seeded at $195 \mathrm{~kg} \cdot \mathrm{ha}^{-1}$ resulted in $11 \%$ greater buffalograss cover than aerification + topdressing seedbed preparation seeded at $145 \mathrm{~kg} \cdot \mathrm{ha}^{-1}$ three MAP.

Ultimately, the invasive cultural practices of aerification and verticutting in combination with topdressing increased buffalograss conversion/establishment. Contrasts resulted in a highly significant $(P<0.001)$ increase in buffalograss cover $(40 \%)$ three MAP when comparing invasive cultural practices (verticutting + topdressing and aerification + topdressing treatments at 146 and $195 \mathrm{~kg} \cdot \mathrm{ha}^{-1}$ ) vs. non-invasive cultural practices (topdressing and no seedbed preparation treatments at 
146 and $195 \mathrm{~kg} \cdot \mathrm{ha}^{-1}$ ) (Table 3). Similarly, the same comparison [invasive cultural practices (verticutting + topdressing and aerification + topdressing treatments) vs. non-invasive cultural practices (topdressing and no seedbed preparation)] not pooled over seeding rates resulted in an increase of $36 \%$ and $42 \%$ buffalograss cover when seeded at $146 \mathrm{~kg} \cdot \mathrm{ha}^{-1}$ and $195 \mathrm{~kg} \cdot \mathrm{ha}^{-1}$, respectively, three MAP (Table 3). Heckman et al. (2002) reported 'Cody', 'Tatanka', and 'Sharp's Improved' buffalograss emergence was greatest at 13-mm buffalograss planting depths. Authors postulate that invasive cultural practices place buffalograss seed within the soil profile where optimal emergence occurs. The use of invasive cultural practices (aerification and verticutting) increases buffalograss cover during establishment, but no difference between aerification and verticutting was observed.

\section{Literature Cited}

Ahring, R.M. and G.W. Todd. 1977. The bur enclosure of the caryopses of buffalograss as a factors affecting germination. Agron. J. 69: 15-17.

Beard, J.B. 1973. Turfgrass: Science and culture. Prentice Hall, New York, NY.

Bowley, S.R. 2008. A hitchhiker's guide to statistics in plant biology. 2nd Ed. Any Old Subject Books, Guelph, Ontario, Canada.

Christians, N. 2011. Fundamentals of turfgrass management. 4th Ed. John Wiley and Sons, Inc., Hoboken, NJ.

Ervin, E.H. and A.J. Koski. 1998. Drought avoidance aspects and crop coefficients of Kentucky bluegrass and tall fescue in the semiarid west. Crop Sci. 38:788-795.

Frank, K.W., R.E. Gaussoin, J.D. Fry, M.D. Frost, and J.H. Baird. 2002. Nitrogen, phosphorus, and potassium effects on seeded buffalograss establishment. HortScience 37:371-373.

Frank, K.W., R.E. Gaussoin, T.P. Riordan, and E.D. Milter. 1998. Date and planting effects on seeded turf-type buffalograss. Crop Sci. 38: 1210-1213.

Frank, K.W., R.E. Gaussoin, T.P. Riordan, R.C. Shearman, J.D. Fry, E.D. Miltner, and P.G. Johnson. 2004. Nitrogen rate and mowing height effects on turf-type buffalograss. Crop Sci. 44:1615-1621.

Fry, J.D. 1995. Establishing buffalograss. Golf Course Mgt. 63:58-60.

Gaitan-Gaitan, F., C.B. McKenney, and D.L. Auld. 1999. Planting rate and caryopses effects on establishment of buffalograss on the southern Great Plains. J. Turfgrass Mgt. 3:1-11.

Griffin, K.A., R. Dickens, and M.S. West. 1994. Imazapyr for common bermudagrass control in sod fields. Crop Sci. 34:202-207.

Harivandi, A. and L. Wu. 1995. Buffalograss-A promising drought resistant turf for California. Univ. of California Coop. Ext. 45:10-12.

Harivandi, A., L. Wu, C. Elmore, and W.L. Hagan. 1995. Buffalograss - A promising drought resistant turf for California. Univ. of California Coop. Ext. 45:7-10.

Hartwiger, C. 2007. No till in no time. USGA Green Section Record 45:22-26.

Heckman, N.L., G.L. Horst, and R.E. Gaussoin 2002. Planting date effect on emergence and morphology of buffalograss seedlings. HortScience 37:506-507.

Henry, J.M., S.N. Wegulo, V.A. Gibeault, and R. Autio. 2005. Turfgrass performance with reduced irrigation and nitrogen fertilizer. Intl. Turfgrass Soc. Res. J. 10:93-101.

Hickey, V.G., F.A. Miller, and M.C. Engelke. 1983. Buffalograss seed pretreatment germination. Texas. Turfgrass Proc. PR 4169. p. 126128.

Johnson, B.J. 1988. Glyphosate and SC-0224 for bermudagrass (Cynodon spp.) cultivar control. Weed Technol. 2:20-23.

Jordan, T.N. 1977. Effects of temperature and relative humidity on the toxicity of glyphosate to bermudagrass (Cynodon dactylon). Weed Sci. 25:448-451.

Kenworthy, K.E., D.L. Auld, D.B. Wester, R.E. Durham, and C.B. McKenney. 1999. Evaluation of buffalograss germplasm for induction of fall dormancy and spring green-up. J. Turfgrass Mgt. 3:23-42.

Kjelgren, R., L. Rupp, and D. Kilgren. 2000. Water conservation in urban landscapes. HortScience 35:1037-1040.

Koski, A.J., Y.L. Qian, S.J. Wilhelm, S. Ball, and Z. Tan. 2001. Freezing tolerance of six cultivars of buffalograss. Crop Sci. 41:1174-1178.

McIntosh, M.S. 1983. Analysis of combined experiments. Agron. J. 75:153-155.
Morris, K.N. 1996. National buffalograss test1991. NTEP Final Rep. No. 96-14. National Turfgrass Evaluation Program, USDA-ARS, Beltsville, MD

Qian, Y.L. and M.C. Engelke. 1999. Performance of five turfgrasses under linear gradient irrigation. HortScience 34:893-896.

Richardson, M.D., D.E. Karcher, and L.C. Purcell. 2001. Quantifying turfgrass cover using digital image analysis. Crop Sci. 41:1884-1888.

Riordan, T.P., P.G. Johnson, R.E. Gaussoin, and J.F. Svoboda. 1997. Seedling germination and establishment of Buchloe dactyloides caryopses vs. burrs. Intl. Turfgrass Soc. Res. J. 8:749756.

Rodiek, J. 1984. Water conserving strategies for the urban arid landscape. Water Conserv. Strat. 6:9-14.

Roundup Pro ${ }^{\circledR}$ Specimen Label. 2010. Monsanto Company, St. Louis, MO.

Severmutlu, S., T.P. Riordan, and R.C. Shearman. 2005a. Registration of 'Cody' buffalograss. Crop Sci. 45:2122-2123.

Severmutlu, S., C. Rodgers, T.P. Riordan, and R.C. Shearman. 2005b. Registration of 'Bowie' buffalograss. Crop Sci. 45:2120-2121.

Shearman, R.C., H. Budak, S. Severmutlu, and R.E. Gaussoin. 2005. Burr seeding rate effect on turf-type buffalograss establishment. HortTechnology 15:246-249.

Sophocleous, M. 2012. Conserving and extending the useful life of the largest aquifer in North America: The future of the High Plains/Ogallala aquifer. Ground Water. doi: 10.1111/j. 1745-6584.2012.00965.x

Turgeon, A.J. 2011. Turfgrass management. 9th Ed. Prentice Hall, Upper Saddle River, NJ.

Wenger, L.E. 1943. Buffalograss. Kansas Agr. Expt. Stn. Manhatten. Bul. 321. p. 1-78.

Wu, L., D.R. Huff, and M.A. Harivandi. 1989. Buffalograss as a low maintenance turf. Calif. Agr. 43:23-25.

$\mathrm{Wu}, \mathrm{L}$. and H. Lin. 1994. Salt tolerance and salt uptake in diploid and polyploid buffalograsses (Buchloe dactyloides). J. Plant Nutr. 17:19051928.

Youngner, Y.B. 1961. Accelerated wear tests on turfgrasses. Agron. J. 53:217-218

Zhang, X., D. Su, L. Ma, and Y. Zhao. 2007. Analysis of genetic diversity in buffalograss determined by random amplified polymorphic DNA markers. HortScience 42:474-477. 